\title{
Advocate Legal Assistance as a Way of Protecting Human Rights
}

\author{
Eddy Riswanto ${ }^{1}$, Suparno $^{2}$ \\ Doctoral of Law, Universitas Borobudur Jakarta \\ \{eddyunborr@gmail.com¹, suparno@borobudur.ac.id²\}
}

\begin{abstract}
Indonesia is a constitutional state, where everyone has the right of recognition, guarantees, protection and legal certainty that is fair and equal treatment before the law regardless of ethnicity, religion or status of life, including people who are unable, to gain access to justice. In a rule of law, the state recognizes and protects human rights for every individual, including the right to legal aid as a guarantee of access to justice which is a strict command of the constitution. So far, the provision of legal aid has not touched many people or groups of poor people, so they find it difficult to access justice because they are hampered by their inability to realize their constitutional rights. Apart from that, it is also due to the frequent occurrence of injustice to people who seek justice, especially for the poor who are economically incapable and do not have access to justice, so the provision of legal aid is very important. Advocates are a part of law enforcers who are obliged to provide free legal assistance (probono nobile) to incapable justice seekers. Therefore, advocates are positioned as "officium nobile", which is a noble and honorable profession. In the judicial system, advocates act as an element of the judicial system which is one of the pillars in upholding the rule of law and human rights. This free legal aid obligation is regulated in Law Number 18 of 2003 concerning Advocates. Regarding separate legal aid, it is regulated in Law Number 16 of 2011 concerning Legal Aid. Therefore, legal aid for advocates is an obligation, which is also part of protecting human rights in obtaining legal guarantees and protection.
\end{abstract}

Keywords: Legal Aid; Advocate; Protection; Human Rights

\section{Introduction}

The 1945 Constitution of the Republic of Indonesia, Article 1 paragraph (3) states that Indonesia is a constitutional state. The definition of a rule of law is a rule of law in a broad sense, namely a state of the law in a material sense. The state not only protects the entire Indonesian nation and the entire homeland of Indonesia but also must promote the general welfare and educate the nation's life [1].

The principle of a rule of law is the guarantee of equality for everyone before the law (equality before the law), which is one of the important characteristics of a rule of law [2]. Therefore, the 1945 Constitution of the Republic of Indonesia, Article 28D paragraph (1), states that "Everyone has the right to recognition, guarantee, protection and legal certainty that is just and equal treatment before the law". This provision is an acknowledgment, 
guarantee, protection, and legal certainty that is just for everyone regardless of ethnicity, religion, or status of life. including people who are unable, to gain access to justice so that their rights to recognition, guarantee, protection, and legal certainty are just, as well as an equal treatment before the law can be realized properly. The position and position of a person before the law is very important in realizing the legal system order, as well as a sense of community justice.

Guarantee for access to legal aid is also clearly stated in Article $28 \mathrm{G}$ paragraph (1), which states that "Every person has the right to protection of himself, family, honor, dignity, and property under his control, as well as to a sense of security and protection. from the threat of fear to do something that is a human right ". This is further strengthened in Article $28 \mathrm{H}$ paragraph (2), which states that "Everyone has the right to get special facilities and treatment to get the same opportunities and benefits to achieve equality and justice". Substantively, the foregoing can be interpreted as guaranteeing access to justice through legal aid, which is a strict command of the constitution.

Concerning legal aid, an advocate is a part of law enforcers who have the task of providing legal assistance to communities (clients) who are experiencing legal problems, so that their existence is urgently needed by the community.

In the Indonesian law enforcement system, advocates have a special position. His specialty lies in the scope of his work as a person whose profession is to provide legal services or legal assistance, both inside and outside the court for people in need. The purpose of this advocate's existence is none other than to ensure the running of a fair legal process (due process of law), as a consequence of the implementation of a rule of law that recognizes, protects, and guarantees the human rights of citizens to access justice and is treated equally in front of. law (equality before the law). Therefore, advocates are positioned as "officium nobile", which is a noble and honorable profession. This can be seen from one of the points of the 1983 Montreal Declaration where advocates are positioned as a profession with noble social duties and functions.

Since it has a noble social duty and function, it makes it so important to provide legal assistance by advocates. An advocate is not allowed to reject a case because there is no money. The absence of fees from the power of attorney does not make the work handled by lawyers odd. An advocate must give the same priority to cases given by capable clients and power providers who are less fortunate. In principle, an advocate is an officium nobile which means a noble and honorable profession, that is, someone who has the profession to provide legal services, both inside and outside the court, which can be in the form of legal consultation, legal aid, exercising power, representing, accompanying, defending and taking action. law for the benefit of clients.

The obligation of free legal aid (probono publico) is regulated in Law Number 18 of 2003 concerning Advocates, Article 22 paragraph (1) states explicitly that, "Advocates are obliged to provide free legal assistance to justice seekers who are unable ". Besides, it is also regulated by Government Regulation Number 83 of 2008 concerning Requirements and Procedures for Providing Free Legal Aid, which stipulates that cases that can be requested for free legal assistance include cases in the fields of criminal, civil, state administration, and criminal. military. Free legal assistance is also provided for non-litigation cases (outside the court). This Government Regulation also regulates the mechanism for submitting applications for the provision of free legal aid submitted by applicants for legal aid to Advocates, Advocate Organizations, and Legal Aid Institutions. Furthermore, it is regulated by Peradi Regulation Number 1 of 2010 concerning Guidelines for the Implementation of Free Legal Aid, as well as the Advocate Code of Ethics. 
The importance of providing legal aid is due to the frequent occurrence of injustice to people who seek justice, especially for the poor who are economically disadvantaged and do not have access to justice. Here, advocates play a role and are obliged to provide legal aid free of charge as a form of moral responsibility for underprivileged people as recipients of legal aid as a manifestation of access to justice which is part of the protection of human rights for legal guarantees and protection. Based on the description above, it is important to research and study legal aid for advocates as a way of protecting human rights. To examine how advocate legal aid is a means of protecting human rights, which is the state's recognition of the right to legal aid guaranteed by the constitution.

\section{Research Problem}

Based on the background described above, the formulation of this research problem can be formulated as follows:

What about advocate legal assistance as a means of protecting human rights?

\section{Research Method}

This research is normative legal research. Normative research is often called doctrinal research, which is research whose object of study is documents of laws and regulations and library materials [3]. The approach used is the statute approach and the conceptual approach. The statute approach is carried out by examining all laws and regulations related to the legal issue being handled [4]. The conceptual approach departs from the views and doctrines developed in the science of law.

\section{Results and Discussion}

In Indonesian positive law, legal aid is regulated in HIR Article 250. This article regulates legal assistance for defendants in certain cases, namely cases that are punishable by death and/or life sentences, although in this article the practice puts the Dutch nation first over priority. indigenous Indonesian nation. For this reason, appointed legal experts are obliged to provide legal assistance free of charge. Although HIR is limited in effect, it can be interpreted as the beginning of the institutionalization of legal aid into Indonesian positive law. Before the existence of laws regulating procedural law, HIR provisions were still in effect. Then in 1970, Law Number 14 of 1970 concerning the Principles of Judicial Power was born, especially Articles 35, 36, and 37 regulating legal aid.

Then issued Law No. 16 of 2011 concerning Legal Aid, what is meant by legal aid is legal services provided by legal aid providers free of charge to legal aid recipients [5]. Meanwhile, according to Law no. 18 of 2003 concerning Advocates, legal aid is legal services provided by advocates free of charge to clients who cannot afford it [6].

In the judicial system, advocates act as an element of the judicial system which is one of the pillars in upholding the rule of law and human rights [7]. An advocate is a person whose profession is to provide legal services, both inside and outside the court who meet the requirements under the provisions of this law [8]. An advocate's main task is to provide legal opinions, as well as legal advice to keep clients away from conflict, while in a judicial institution (proceeding in court) an advocate proposes or defends the interests of his clients. 
Advocates in handling free cases must pay the same attention to cases for which they receive money [10].

Sidik Sunaryo argues that as one of the pillars (sub-systems), the presence of advocates is very important in the context of realizing an honest, fair, clean trial, ensuring legal certainty and certainty of justice and human rights guarantees [11]. Furthermore, he also stated that the function of an advocate is to defend clients and to ensure that the client's rights are fulfilled in the judicial process [12]. The existence of an advocate is very much needed by people who seek justice and legal certainty, especially the poor who do not understand the law so that they are not treated arbitrarily by other law enforcers. Besides, an advocate must devote himself to society so that he is required to always participate in the enforcement of human rights [13].

An advocate who carries out social duties and functions as an "officium nobile". For the state, the existence of advocates is recognized as part of the Chess Wangsa law enforcement in addition to judges, prosecutors, and police so that they are called "officers of the court". With this existence, an advocate in carrying out his profession also acts as a guardian of the constitution and human rights (the guardian of the constitution and human rights). Advocates play an important role in fighting for human rights which are the most basic rights of every citizen.

The above statement is in line with that put forward by Ropaun Rambe, who gives pointers on the function and role of an advocate which shows the importance of an advocate as a free and independent profession. The pointers of the function and role of this advocate are as guardians of the constitution and human rights, fight for human rights in the Indonesian rule of law, and provide free legal aid to people who are weak and underprivileged [14]. Clients are people, legal entities, or other institutions that receive legal services from lawyers [15]. As for what is meant by recipients of legal aid are people or groups of poor people [16]. Furthermore, legal aid providers are legal aid institutions or social organizations that provide legal aid services based on this law [17].

Legal aid is implemented based on the principles of justice, equality in law, openness, efficiency, effectiveness, and accountability [18]. The implementation of legal aid aims at guaranteeing and fulfilling the rights of legal aid recipients to gain access to justice, realizing the constitutional rights of all citizens under the principle of equality in law, ensuring certainty that legal aid is implemented evenly throughout the territory of the Republic of Indonesia, and realizing an effective, efficient, and accountable justice [19]. The legal basis for providing legal aid to poor people is based on the following provisions:

a. Law of the Republic of Indonesia Number 48 of 2009 concerning Judicial Power, Article 56, which states: Every person involved in a case has the right to legal assistance.

b. Law Number 8 of 1981 concerning the Criminal Procedure Code, Article 54, which states: For the sake of defense, a suspect or defendant has the right to receive legal assistance from one or more legal advisors during the time and at each level of examination, according to the procedure stipulated in this law.

c. Law Number 8 of 1981 concerning the Criminal Procedure Code, Article 56 paragraph (1), which states: If a suspect or defendant is suspected or charged with committing a death penalty or the penalty of fifteen years or more those who are incapacitated who are punished with a sentence of five years or more who do not have their legal advisers, the officials concerned at all levels of examination in the trial process are obliged to appoint legal advisors for them.

d. Law Number 8 of 1981 concerning the Criminal Procedure Code, Article 56 paragraph (2), which states: Every legal advisor appointed to act as referred to in paragraph (1) shall assist free of charge. 
e. The Code of Civil Procedure Code (HIR / RBG) Article 237 HIR / 273 RBG, which states: Whoever wants to litigate either as a plaintiff or as a Defendant, but is unable to bear the costs, can obtain permission to litigate for free.

f. Instruction of the Minister of Justice of the Republic of Indonesia No. M 01-UM.08.10 of 1996, concerning the Guidelines for the Implementation of Legal Aid Programs for People with Disabilities through Legal Aid Institutions.

g. Instruction of the Minister of Justice of the Republic of Indonesia No. M 03-UM.06.02 of 1999, concerning Guidelines for the Implementation of Legal Aid Programs for Poor People through District Courts and State Administrative Courts.

h. Circular of the Director-General of General Courts and State Administrative Courts No. D.Um.08.10.10 dated 12 May 1998 concerning the JUKLAK for the Implementation of Legal Aid for the Poor through LBH.

Providing legal assistance (defense) for underprivileged people can only be done by lawyers who have been registered at the local High Court. Provision of legal assistance can be done through:

a. Legal assistance (defense) carried out by individual advocates.

b. Legal assistance (defense) carried out by advocates as an institution through the Institute.

c. Local Legal Aid.

Legal assistance from advocates is conceptualized as a right whose data is demanded by every Indonesian citizen. This right is seen as part of human rights so that the legal aid program in Indonesia is essentially a program to fight for the enforcement of human rights.

The importance of the role of advocates in defending and protecting the interests of the fundamental rights of justice seekers is recognized by the international community as reflected in the "Basic Principle on The Role of Lawyers" adopted by the 8th Crime Congress in Havana, Cuba, 27 August - 7 September 1990 In this regard, it was argued, among other things, that programs to provide information about rights and obligations under the law and the importance of the role of the defender in protecting the rights of fundamental freedoms must always be encouraged. Those who are poor or unfortunate who cannot fight for their rights are assisted in obtaining legal assistance as soon as possible [20].

The right to legal aid as protection of human rights has been universally accepted as guaranteed in the International Covenant on Civil and Political Rights (ICCPR), which was later accommodated and ratified by Law No.12 2005 concerning the Ratification of the International Covenant on Civil and Political Rights (International Covenant on Civil and Political Rights). Articles 16 and 26 of the ICCPR guarantee that all people have the right to legal protection, and must be protected from all forms of discrimination. Meanwhile, Article 14 paragraph (3) of the ICCPR provides conditions related to assistance, namely: 1) interests of justice and 2) unable to pay advocates.

Then the Universal Declaration of Human Rights, Article 10 states "Everyone, in full equality, has the right to a fair and open trial by a free and impartial court, in determining his rights and obligations and in every criminal charge that is brought against him".

In Indonesia, legal aid is not explicitly stated as the responsibility of the state, but in the provisions of the 1945 Constitution of the Republic of Indonesia, Article 1 paragraph (3) states that "the State of Indonesia is a state of law". In a rule of law, the state recognizes and protects human rights for every individual, including the right to legal aid. The provision of legal aid to citizens to fulfill and at the same time implement a rule of law that recognizes and protects and guarantees the human rights of citizens regarding the need for access to justice and equality before the law. 
According to Padmo Wahjono, a country is called a rule of law if there is a pattern to respect and protect human rights, there is a democratic state institutional mechanism, there is a legal order, and there is free judicial power [21]. These things do not deviate from the principles of democracy, which recognize the sovereignty of the people. Meanwhile, according to Julius Stahl, the concept of a rule of law which he calls rechtsstaat includes four important elements, one of which is the protection of human rights [22] Indonesia as a country of law, one of which protects human rights is in the form of the right to legal aid, which is then manifested in the form of law, namely Law no. 16 of 2011 concerning Legal Aid.

That the state was formed to protect the rights of citizens. Aristotle argues that the State is intended for the benefit of its citizens so that they can live well and happily [23]. Jimly Asshiddiqie initiated twelve main principles as the main pillars that support the establishment of a rule of law, including the supremacy of law, equality before the law, due process of law, limitation of power, independent supporting organs, free and impartial judiciary, state administrative court, constitutional court, protection of human rights, democratic in nature (democratishe rechtsstaat), function as a means of realizing the goal of a state (welfare rechtsstaat) and transparency and social control [24].

In the context of human rights, the right to obtain legal guarantees and protection, apart from being regulated in the constitution, is also universally contained in the Universal Declaration of Human Rights, Article 10, which states "Everyone, in full equality, has the right to a fair and open trial. by a free and impartial court, in determining his rights and obligations as well as in any criminal charges imposed on him ".

In the Charter of Human Rights, Part II, Chapter IV concerning the Right to Justice, the rights of individuals in law are regulated, namely in Article 7, which states that "Everyone has the right to recognition, guarantee, protection, and fair legal treatment". Then Article 8, which reads that "Everyone has the right to legal certainty and equal treatment before the law". Decree of the People's Consultative Assembly of the Republic of Indonesia Number XVII / MPR / 1998 concerning Human Rights, which explains that the substance of human rights includes; right to live; right to have a family and continue the offspring; the right to selfdevelopment; right to justice; freedom rights; right to communicate; security rights; and welfare tubs.

Then by Law Number 39 of 1999 concerning Human Rights, Chapter II, Article 3 paragraph (2), which reads, "Everyone has the right to recognition, guarantees, protection, and fair legal treatment and to receive legal certainty in the spirit ahead law". Then regulated in Article 5 paragraph (1) and (2). Next is the Presidential Decree of the Republic of Indonesia Number 50 of 1993 concerning the National Commission on Human Rights, in Chapter II, Article 4, which regulates the objectives of the National Commission, namely:

a. Assist in the development of conditions conducive to the implementation of human rights under Pancasila, the 1945 Constitution, and the Charter of the United Nations, and the Universal Declaration of Human Rights;

b. Increasing the protection of human rights to support the realization of the national development goals, namely the development of the whole Indonesian human being and the development of the whole Indonesian society.

Article 5, letter c, the same decree states "Monitor and investigate the implementation of human rights and provide opinions, considerations, and suggestions to State government agencies regarding the implementation of human rights" which in this context can be interpreted as providing legal assistance to disadvantaged/poor society.

All of these provisions were then strengthened mainly by the issuance of Law Number 16 of 2011 concerning Legal Aid and previously Law Number 18 of 2003 concerning Advocates 
was issued as the implementing regulation for the provision of legal aid which places advocates as the main subject of providing legal aid.

Based on the explanation described above, legal aid by lawyers is a means of protecting human rights. Also, providing free legal assistance (probono publico) to justice seekers who cannot afford is the duty of every lawyer. This obligation is a moral responsibility of an advocate as a noble and honorable profession (officium nobile).

\section{Conclusion and Suggestion}

\subsection{Conclusion}

Based on the constitution, Indonesia is a constitutional state. The principle of a rule of law is the guarantee of equality for everyone before the law (equality before the law), which is one of the important characteristics of a rule of law. In a rule of law, the state recognizes and protects human rights for every individual, including the right to legal aid. Advocates are a part of law enforcers who are obliged to provide free legal assistance (probono nobile) to incapable justice seekers. Therefore, advocates are positioned as "officium nobile", which is a noble and honorable profession. Advocate legal aid is a means of protecting human rights.

\subsection{Suggestion}

a. The need for the socialization of legal aid as a means of protecting human rights should be increased, especially for those who are experiencing legal problems, and the procedure for obtaining legal aid for people who cannot afford it should be facilitated.

b. Advocate organizations should further increase the socialization of the Advocate Law to the public, especially regarding their obligation to provide free legal assistance as a means of protecting human rights.

\section{References}

[1] Masriani, Yulies Tiena.: Pengantar Hukum Indonesia. Sinar Grafika, Jakarta (2006).

[2] Asshiddiqie, Jumly.: Pokok-Pokok Hukum Tata Negara Indonesia Pasca Reformasi. Bhuana Ilmu Populer, Jakarta (2007).

[3] Soejono dan H. Abdurahman.: Metode Penelitian Hukum. Rineka Cipta Jakarta (2003).

[4] Marzuki, Peter Mahmud.: Penelitian Hukum. Edisi Revisi. Prenada Kencana, Jakarta (2014).

[5] Undang-Undang Republik Indonesia Nomor 16 Tahun 2011 tentang Bantuan Hukum.

[6] Undang-Undang Republik Indonesia Nomor 18 Tahun 2003 tentang Advokat.

[7] Hatta, Moh.: Beberapa Masalah Penegakan Hukum Pidana Umum dan Pidana Khusus. Liberty, Yogyakarta (2009).

[8] Hatta, Moh.: Beberapa Masalah Penegakan Hukum Pidana Umum dan Pidana Khusus. Liberty, Yogyakarta (2009).

[9] Kansil, C.S.T.: Pokok-Pokok Etika Profesi Hukum. Pradnya Paramita, Jakarta (2003).

[10] Supriyadi.: Etika dan Tanggung Jawab Profesi Hukum di Indonesia. Sinar Grafika, Jakarta (2006). 
[11] Sunaryo, Sidik.: Kapita Selekta Sistem Peradilan Pidana. Universitas Muhammadiyah Malang, Malang (2004).

[12] Sunaryo, Sidik.: Kapita Selekta Sistem Peradilan Pidana. Universitas Muhammadiyah Malang, Malang (2004).

[13] Winata, Frans Hendra.: Advokat Indonesia, Citra, Idealisme dan Kepribadian. Sinar Harapan, Jakarta (1995).

[14] Ropaun Rambe.: Teknik Praktek Advokat. Gramedia Widiasarana Indonesia, Jakarta (2001)

[15] Undang-Undang Republik Indonesia Nomor 18 Tahun 2003 tentang Advokat.

[16] Undang-Undang Republik Indonesia Nomor 16 Tahun 2011 tentang Bantuan Hukum.

[17] Undang-Undang Republik Indonesia Nomor 16 Tahun 2011 tentang Bantuan Hukum.

[18] Undang-Undang Republik Indonesia Nomor 16 Tahun 2011 tentang Bantuan Hukum.

[19] Undang-Undang Republik Indonesia Nomor 16 Tahun 2011 tentang Bantuan Hukum.

[20] Kunarto.: Ikhtiar Implementasi Hak Asasi Manusia Dalam Penegakan Hukum. Cipta Manunggal, Jakarta (1997).

[21] Wahjono, Padmo.: Indonesia Negara Berdasarkan Atas Hukum. Ghalia Indonesia, Jakarta (1993).

[22] Asshiddiqie, Jimly.: Konstitusi dan Konstitusionalisme Indonesia. Cet. 1, Mahkamah Konstitusi Republik Indonesia dan Pusat Studi Hukum Tata Negara Fakultas Hukum Universitas Indonesia, Jakarta (2004).

[23] Astawa, I Gde Pantja dan Suprin Na'a.: Memahami Ilmu Negara dan Teori Negara. Refika Aditama, Bandung (2009).

[24] Asshiddiqie, Jimly.: Konstitusi dan Konstitusionalisme Indonesia. Cet. 1, Mahkamah Konstitusi Republik Indonesia dan Pusat Studi Hukum Tata Negara Fakultas Hukum Universitas Indonesia, Jakarta (2004). 